\title{
Environmentally Friendly Biosorbent from Moringa Oleifera Leaves for Water Treatment
}

\author{
Eman N. Ali, Sabreen R. Alfarra, Mashita Mohd Yusoff, and Md Lutfor Rahman
}

\begin{abstract}
In this study Moringa oleifera leaves (biosorbent) is used for Cadmium (II) removal from water as a natural alternative for synthetic sorbents. Synthetic water was used to find optimum conditions for water treatment using biosorbent. The effect of biosorbent dosage and particle size, contact time, and $\mathbf{p H}$ effect were studied. Atomic Absorption Spectroscopy (AAS) was used to monitor the Cd (II) concentration before and after treatment with biosorbent. Fourier Transform Infrared Spectroscopy (FTIR) was used to monitor biosorbent structure changes before and after loading with Cd (II). Many parameters were studied such as: dosage of biosorbent $(1-10$ $\mathrm{g} / \mathrm{L})$, contact time $(2-20 \mathrm{~min})$, particle size $(2 \mathrm{~mm}, 1 \mathrm{~mm}, 500$ $\mu \mathrm{m}, 250 \mu \mathrm{m}$, and $<250 \mu \mathrm{m})$, $\mathrm{pH}$ range $(4-10)$, and $\mathrm{Cd}$ (II) concentrations $(1,3,5$, and $7 \mathrm{ppm})$. The statistical analysis of studied parameters showed that all parameters has an effect on Cd (II) removal with $p$ values $<0.05$ except $p H$. FTIR result showed changes in the finger print area of biosorbent functional groups due to adsorption of $\mathrm{Cd}$ (II). As a conclusion, Moringa oleifera leaves can be used as an effective, low cost, and environmentally friendly biosorbent for the removal of $\mathrm{Cd}$ (II) from water.
\end{abstract}

Index Terms-Biosorption, Cadmium (II), Moringa oleifera, water treatment.

\section{INTRODUCTION}

Every day, there are thousands of chemicals discharged directly and indirectly into water bodies without further treatment for elimination of the included harmful compounds.

Heavy metals are without doubt well thought-out as the most hazardous and harmful metals even if they present as traces in water, since they accumulate in the tissue of living organism.

$\mathrm{Cd}$ (II) is one of the most toxic and hazardous heavy metal and it is responsible for causing kidney damage, renal disorder, high blood pressure, bone fraction, and destruction of red blood cells [1]. Major sources of $\mathrm{Cd}$ (II) in

Manucript received June 6, 2014; revised July 20, 2014. This work was supported by Research \& Innovation Department/ Universiti Malaysia Pahang / Malaysia, under grant \#: RDU 140318.

Eman N. Ali is with the Faculty of Chemical \& Natural Resources Engineering, Universiti Malaysia Pahang, Gambang, 26300 Kuantan, Pahang, Malaysia (e-mail: eman@ump.edu.my).

Sabreen R. Alfarra is with Universiti Malaysia Pahang, Gambang, 26300 Kuantan, Pahang, Malaysia.

Mashita Mohd Yusoff and Md Lutfor Rahman are with the Faculty of Industrial Sciences \&Technology, Universiti Malaysia Pahang, Gambang, 26300 Kuantan, Pahang, Malaysia. environment are electroplating, industries of pigments, plastic, and metal finishing industries.

Removal of Cd (II) from aqueous solutions can be accomplished by several techniques such as chemical precipitation, ion exchange, membrane separation and adsorption. Though, currently used methods contain several restrictions in the removal of $\mathrm{Cd}$ (II) from water [2]. Such methods showed to be not effective and not economically possible for the treatment of low heavy metal concentrations [3].

As a result, removal and eliminating of $\mathrm{Cd}$ (II) in the polluted water has become a vital mission and essential environmental goal to search for appropriate alternative solutions. Biosorption of $\mathrm{Cd}$ (II) by agricultural waste materials is one of these alternative treatment methods, because of its simplicity and availability [4], [5].

Many studies were conducted to develop an effective removal of heavy metals using biosorbents, such as microbial biomass [6], and agricultural waste materials such as: sugar cane bagasse fly ash and peat [7], rice husks and straws [8], soya bean, saw dust, walnut and cotton seeds hull, corn cobs, and banana peels [9].

Recently, researchers are paying attention on the removal of Cd (II) from aqueous solution using adsorbents derived from low-cost tree leaves such as loquat leaves (Eriobotrya japonica) [10], Psidium guajava leaves [11], Maize leaves [12], Ulmus leaves [13], Scolymus hispanicus [14], Ulmus carpinifolia and Fraxinus excelsior tree leaves [15], fig leaves [16], Azadirachta indica (Neem leaves) [17], Olea europaea (Olive leaves) [18], and Prunus vium leaves [19].

In this work, the effect of dosage of Moringa oleifera leaves, contact time, biosorbent particle size, and $\mathrm{pH}$ on $\mathrm{Cd}$ (II) removal from water was examined. The results of this study can be used to evaluate the efficacy of Moringa oleifera leaves for $\mathrm{Cd}$ (II) removal from water and may replace activated carbon in water treatment industry.

\section{MATERIALS AND METHODS}

\section{A. Biosorbent Preparation}

Moringa oleifera leaves were collected from nearby area of Universiti Malaysia Pahang, Kuantan, Pahang, Malaysia. Leaves were dried in sunlight for 1 day. After drying, leaves were grounded using electrical grinder, followed be sieving to different particle size $(2 \mathrm{~mm}, 1 \mathrm{~mm}, 500 \mu \mathrm{m}, 250 \mu \mathrm{m}$, and $<250 \mu \mathrm{m}$ ) then kept in plastic bags at room temperature to be used in the study.

\section{B. Synthetic Water Preparation}

A weight of 5 gm of kaolin, laboratory grade (k7375-500G 
Sigma- Aldrich) was dissolved with $500 \mathrm{ml}$ of distilled water. Sodium bicarbonate solution with concentration of $100 \mathrm{mg} / \mathrm{L}$ was prepared by adding $100 \mathrm{mg}$ of sodium bicarbonate (Hamburg Chemicals) to $1000 \mathrm{ml}$ of distilled water; Adding $500 \mathrm{ml}$ of the sodium bicarbonate solution to the kaolin. The suspension was stirred for about 1 hour at $200 \mathrm{rpm}$ to achieve a uniform dispersion of kaolin particles. Then it was left for at least 24 hours for complete hydration of the kaolin [20]. The synthetic turbid water was used for biosorption test on Cd (II) removal from water by Moringa oleifera leaves. This stock was diluted a few times to get the turbidity needed for each particular test.

\section{Biosorption Experiments}

The jar test is a commonly used method to evaluate coagulation- flocculation processes [21]. Biosorption tests were carried out using the jar test equipment. Six beakers were filled with $500 \mathrm{ml}$ of the synthetic water and known quantity of Cd (II) $(0.5,1.5,2.5$, and $3.5 \mathrm{ml}$ of $1000 \mathrm{mg} / \mathrm{L}$ stock solution) were added to $500 \mathrm{ml}$ of synthetic water to get the Cd (II) concentration of (1, 3, 5, and $7 \mathrm{ppm})$. A different dose of Moringa oleifera leaves of ( 1 to $10 \mathrm{~g}$ ) was added to the synthetic water, the sample was mixed with biosorbent at $200 \mathrm{rpm}$ for 60 minutes, the suspension was allowed to settle for 30 minutes then the biosorbent was filtered using Whatman filter paper No. 42. The residual Cd (II) in water was analyzed using AAS at wave length of 228.8 using an acetylene air flame. A triplicate test was performed for every sample to get average of reproducing results. $\mathrm{RE}$ of $\mathrm{Cd}$ (II) was calculated using the equation: $\mathrm{RE} \%=\left[\left(C_{o}-C_{e}\right) / C_{o}\right] \times$ 100, where: $C_{o}$ and $C_{e}$ are the initial and residual concentration of $\mathrm{Cd}$ (II) in water $(\mathrm{mg} / \mathrm{L})$, respectively [10], [19].

\section{Equipments}

The concentrations of $\mathrm{Cd}$ (II) in the solutions before and after biosorption were determined by AAS 400 (Perkin Elmer). The $\mathrm{pH}$ of the solution was measured with a (Mettler Toledo) pH meter using combined glass electrode. Turbidity measurement was conducted using (Hach 2100Q) turbidity meter for synthetic water used in the experiments. FTIR (Perkin Elmer) was used to identify the different functional groups present in the Moringa oleifera leaves before and after removing Cd (II). FTIR analyses also used to determine the functional groups which are responsible for the $\mathrm{Cd}$ (II) binding with Moringa oleifera leaves. The analysis was carried out using $\mathrm{KBr}$ pellet and the spectral range varying from 4000 to $400 \mathrm{~cm}^{-1}$.

\section{E. Biosorption Study}

Adsorption of $\mathrm{Cd}$ (II) in synthetic water on Moringa oleifera leaves were examined by different parameters such as dose concentration (1 -10 g/L), contact time (2 - $20 \mathrm{~min})$, particle size ( $2 \mathrm{~mm}, 1 \mathrm{~mm}, 500 \mu \mathrm{m}, 250 \mu \mathrm{m}$, and < $250 \mu \mathrm{m})$, Cd (II) concentration (1, 3, 5, and $7 \mathrm{ppm})$. The water $\mathrm{pH}$ varied from 4 to 10 , the $\mathrm{pH}$ of water was adjusted by using $0.1 \mathrm{~N} \mathrm{HCl}$ or $0.1 \mathrm{~N} \mathrm{NaOH}$ without changing the volume of the sample.

Multi diluted standards of 1, 3, 5 and 7 ppm of $\mathrm{Cd}$ (II) in this study were prepared from standard stock solution (1000 $\mathrm{mg} / \mathrm{L})$.

\section{RESUlTS AND DisCUSSION}

The effect of different parameters was studied and the results showed different RE\% with different concentration of Cd (II).

\section{A. Biosorbent Dose Effect}

The biosorbent dosage is an important parameter to determine the capacity of a biosorbent for a given initial concentration. Biosorption of $\mathrm{Cd}(\mathrm{II})$ onto Moringa oleifera leaves was studied by adding different dosage of Moringa oleifera leaves from 1 to $10 \mathrm{~g} / \mathrm{L}$ in the treated water sample using different initial Cd (II) concentration of (1, 3, 5, and 7 ppm) and constant contact time of $60 \mathrm{~min}$. Statistical analysis showed that the dose has an effect on the removal of Cd (II) with different concentration from synthetic water. $P$ value for $1 \mathrm{ppm}, 3 \mathrm{ppm}, 5 \mathrm{ppm}$, and $7 \mathrm{ppm}$ were $0.00078,0.000716$, 0.000571 and 0.000629 , respectively which is $<0.05$.

Fig. 1 shows the removal efficiency for Cd (II) biosorption by Moringa oleifera leaves at different Cd (II) concentration. The percentage of the metal biosorption sharply increased when the biosorbent dosage increased. This result might be explained by the fact that the biosorption sites increases by increasing the biosorbent dosage [10]. Evidently, the maximum RE for 1 ppm was $81 \%$ with optimum dosage of 6 $\mathrm{gm} / \mathrm{L}$, while it was $74 \%, 64 \%$ and $72 \%$ for the $\mathrm{Cd}(\mathrm{II})$ concentration of $3 \mathrm{ppm}, 5 \mathrm{ppm}$, and $7 \mathrm{ppm}$, with optimum dosage of biosorbent $6 \mathrm{~g} / \mathrm{L}, 5 \mathrm{~g} / \mathrm{L}$, and $8 \mathrm{~g} / \mathrm{L}$, respectively. Therefore, the determined optimum doses obtained from this part of the experiments were used in the next stages of study.

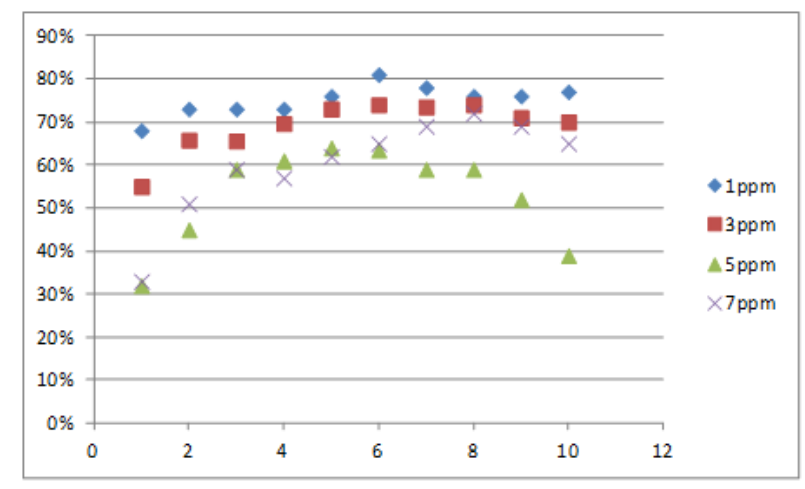

Fig. 1. RE\% with different biosorbent dose.

\section{B. Contact Time Effect}

The effect of contact time on the biosorption process was studied within time range from 2 to $20 \mathrm{~min}$ at the optimum doses mentioned above for the different $\mathrm{Cd}$ (II) concentration. It can be seen from Table I, that the RE was increased by increasing the contact time. RE of $72.1 \%$ was achieved for $\mathrm{Cd}$ (II) removal with concentration of $1 \mathrm{ppm}$ with $p$ value of 0.003366 . Statistical analysis results showed that the time has an effect in the first 20 min with $p$ value of $0.007453,0.005871$, and 0.005098 for $3 \mathrm{ppm}, 5 \mathrm{ppm}$, and 7 ppm Cd (II) concentration, and RE of $72 \%, 68 \%$, and $71 \%$, respectively at $18 \mathrm{~min}$ contact time.

\section{Biosorbent Particle Size Effect}

The effect of the biosorbent particle size on the biosorption process was studied using different sizes of Moringa oleifera leaves. The particle sizes used in this experiment were (2 
$\mathrm{mm}, 1 \mathrm{~mm}, 500 \mu \mathrm{m}, 250 \mu \mathrm{m}$, and $<250 \mu \mathrm{m})$. It was noted that the RE\% was very low when $2 \mathrm{~mm}$ and $1 \mathrm{~mm}$ material were used, and this was probably due to smaller surface area of the biosorbent. On the other hand, statistical analysis showed that particle sizes of $500 \mu \mathrm{m}, 250 \mu \mathrm{m}$, and $<250 \mu \mathrm{m}$ have an effect on Cd (II) removal with $p$ values $<0.05$. Table II, shows the RE\% using different particle sizes. It can be observed that the highest RE\% was achieved by applying Moringa oleifera leaves with particle size of $<250 \mu \mathrm{m}$ to remove $81 \%$ of $\mathrm{Cd}$ (II) in treated water.

\begin{tabular}{|l|l|l|l|l|}
\multicolumn{5}{c}{ TABLE I: CONTACT TIME EFFECT ON RE\% } \\
\hline \multirow{2}{*}{ Time (min) } & \multicolumn{4}{l}{ Cd (II) concentration (ppm) } \\
\cline { 2 - 5 } & $1 \mathrm{ppm}$ & $3 \mathrm{ppm}$ & $5 \mathrm{ppm}$ & $7 \mathrm{ppm}$ \\
\hline 2 & $26 \%$ & $23 \%$ & $13 \%$ & $22 \%$ \\
\hline 4 & $18 \%$ & $27 \%$ & $17 \%$ & $24 \%$ \\
\hline 6 & $20 \%$ & $11 \%$ & $18 \%$ & $23 \%$ \\
\hline 8 & $23.30 \%$ & $11 \%$ & $14 \%$ & $18 \%$ \\
\hline 10 & $20 \%$ & $19 \%$ & $18 \%$ & $21 \%$ \\
\hline 12 & $29.40 \%$ & $25 \%$ & $55.50 \%$ & $14 \%$ \\
\hline 14 & $69 \%$ & $66 \%$ & $67 \%$ & $63 \%$ \\
\hline 16 & $72.10 \%$ & $65.50 \%$ & $65.40 \%$ & $64 \%$ \\
\hline 18 & $71 \%$ & $72 \%$ & $68 \%$ & $71 \%$ \\
\hline 20 & $70 \%$ & $64 \%$ & $66.40 \%$ & $65 \%$ \\
\hline
\end{tabular}

TABLE II: PARTICLE SIZE EFFECT ON RE\%

\begin{tabular}{|c|c|c|c|c|}
\hline Biosorbent & \multicolumn{4}{|c|}{ RE\% using different } \\
\hline Particle size & $1 \mathrm{ppm}$ & $3 \mathrm{ppm}$ & $5 \mathrm{ppm}$ & $7 \mathrm{ppm}$ \\
\hline $2 \mathrm{~mm}$ & $9.10 \%$ & $9.11 \%$ & $5.15 \%$ & $8 \%$ \\
\hline $1 \mathrm{~mm}$ & $10.20 \%$ & $5.23 \%$ & $4.57 \%$ & $13 \%$ \\
\hline $500 \mu \mathrm{m}$ & $75.00 \%$ & $72 \%$ & $71.00 \%$ & $66 \%$ \\
\hline $250 \mu \mathrm{m}$ & $76.70 \%$ & $71.20 \%$ & $76 \%$ & $76 \%$ \\
\hline$<250 \mu \mathrm{m}$ & $81 \%$ & $74 \%$ & $64 \%$ & $72 \%$ \\
\hline
\end{tabular}

\section{D. $p H$ Effect}

The effect of $\mathrm{pH}$ on the biosorption of $\mathrm{Cd}$ (II) onto biosorbent was studied at $\mathrm{pH}$ range of 4-10. It was found that there is no effect of $\mathrm{pH}$ on the biosorption of $\mathrm{Cd}$ (II). Table III, shows RE\% of Cd (II) was in the range of $55 \%$ to $65 \%$ and there is no much difference in Cd (II) removal. Statistical analysis showed that $\mathrm{pH}$ has no effect because the $p$ value was $>0.05$. Therefore, $\mathrm{pH}$ considered as insignificant factor in water treatment process using Moringa oleifera leaves as biosorbent.

TABLE III: pH EFFECT ON RE\%

\begin{tabular}{|c|c|c|c|c|}
\hline \multicolumn{5}{c|}{ TABLE III: pH EFFECT ON RE\% } \\
\hline \multirow{2}{*}{$\mathrm{pH}$} & \multicolumn{4}{|c|}{ Cd (II) concentration (ppm) } \\
\cline { 2 - 5 } & $1 \mathrm{ppm}$ & $3 \mathrm{ppm}$ & $5 \mathrm{ppm}$ & $7 \mathrm{ppm}$ \\
\hline 4 & $65.38 \%$ & $56.65 \%$ & $60.40 \%$ & $58.49 \%$ \\
\hline 5 & $63.34 \%$ & $65 \%$ & $64.60 \%$ & $56.95 \%$ \\
\hline 6 & $59.63 \%$ & $58.30 \%$ & $64.60 \%$ & $56.80 \%$ \\
\hline 7 & $64.23 \%$ & $60 \%$ & $58.20 \%$ & $57.87 \%$ \\
\hline 8 & $62.60 \%$ & $57.79 \%$ & $58.70 \%$ & $55.41 \%$ \\
\hline 9 & $65.67 \%$ & $59.39 \%$ & $56.59 \%$ & $57.36 \%$ \\
\hline 10 & $60.30 \%$ & $58.62 \%$ & $61.64 \%$ & $57.56 \%$ \\
\hline
\end{tabular}

\section{E. Water Turbidity Effect}

Moringa oleifera leaves as biosorbent for Cd (II) removal was also investigated on different water turbidities using the optimum doses mentioned above for each concentration of Cd (II). Table IV shows the different turbidites and the optimum RE\% for each Cd (II) concentration. It was found that the optimum RE\% was achieved when the water turbidity was $50 \mathrm{NTU}$ with $83.40 \%$ at Cd (II) concentration of $1 \mathrm{ppm}$.

TABLE IV: WATER TURBIDITY EFFECT ON RE\%

\begin{tabular}{|c|c|c|c|c|}
\hline Turbidity & \multicolumn{4}{|c|}{ Cd (II) concentration (ppm) } \\
\hline (NTU) & $1 \mathrm{ppm}$ & $3 \mathrm{ppm}$ & $5 \mathrm{ppm}$ & $7 \mathrm{ppm}$ \\
\hline 50 & $83.40 \%$ & $61.60 \%$ & $61.50 \%$ & $60.60 \%$ \\
\hline 200 & $81 \%$ & $74 \%$ & $64 \%$ & $72 \%$ \\
\hline 400 & $62 \%$ & $62.60 \%$ & $48.30 \%$ & $48.30 \%$ \\
\hline
\end{tabular}

\section{F. FTIR Analysis}

FTIR was used to investigate the functional groups of Moringa oleifera leaves and Cd (II) loaded on Moringa oleifera leaves. FTIR study was carried out and the spectra are shown in Fig. 2 and 3. The Moringa oleifera leaves display a number of absorption peaks, reflecting their complex nature. The 2D FTIR spectrum (Fig. 2) shows the Moringa oleifera leaves before and after biosorption of $\mathrm{Cd}$ (II). Fig. 2A shows that Moringa oleifera leaves in nature has two peaks which is considered as the finger print of Moringa oleifera leaves, while Fig. 2B shows those peaks after biosorption of $\mathrm{Cd}$ (II) are merged to be one strong peak, which means that $\mathrm{Cd}$ (II) is affecting the Moringa oleifera leaves structure.

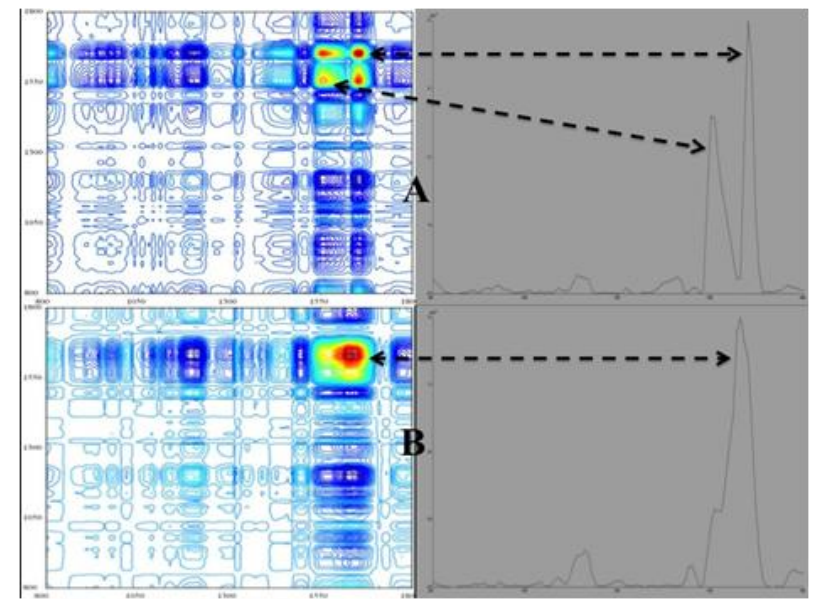

Fig. 2. 2D FTIR spectrum of Moringa oleifera leaves before (A), and after (B) biosorption of $\mathrm{Cd}$ (II)

Fig. 3 shows 1D FTIR for a comparison of the transmittance of Moringa oleifera leaves contents before and after biosorption of $\mathrm{Cd}$ (II), the lower graph is the original peaks of Moringa oleifera leaves while the upper is the Moringa oleifera leaves loaded with Cd (II). It shows the absorption peaks at $2919.70 \mathrm{~cm}^{-1}$ and $2850.87 \mathrm{~cm}^{-1}$ were elongated and sharpened, this could be because of the $\mathrm{C}-\mathrm{H}$ stretching off $-\mathrm{C}=\mathrm{O}$ and/or $-\mathrm{CH}_{3}$ of functional groups. At absorption peak $1653.76 \mathrm{~cm}^{-1}$ there was elongation in the peak due to the stretch in the $\mathrm{C}=\mathrm{O}$ functional group of the carboxylic acids. It was noted also that the peak at 1412.16 $\mathrm{cm}^{-1}$ was shifted to $1436.01 \mathrm{~cm}^{-1}$ and the peak at $1239.05 \mathrm{~cm}^{-1}$ shifted to $1243.19 \mathrm{~cm}^{-1}$ and this was due to the stretching of 
C-O of the functional groups. Peak at $1317.11 \mathrm{~cm}^{-1}$ also has an elongation and this might be because of the $\mathrm{N}=\mathrm{O}$ bending in the functional groups. Another change was noted on the natural composition of Moringa oleifera leaves which is the existence of peaks at wave number of $1378.01 \mathrm{~cm}^{-1}, 1155.9$ $\mathrm{cm}^{-1}$, and $1032 \mathrm{~cm}^{-1}$. The repeated shift due to the $\mathrm{C}-\mathrm{O}$ stretching suggests that $\mathrm{C}-\mathrm{O}$ might be a functional group that $\mathrm{Cd}$ (II) can bind and react with it. In addition, it can be said that the shift in the absorption peaks generally observed and might indicate the existence of $\mathrm{Cd}$ (II) binding process on the surface of the Moringa oleifera leaves. The obtained results were in agreement with [10] results with some differences, and this might be because of different source of Moringa oleifera leaves.

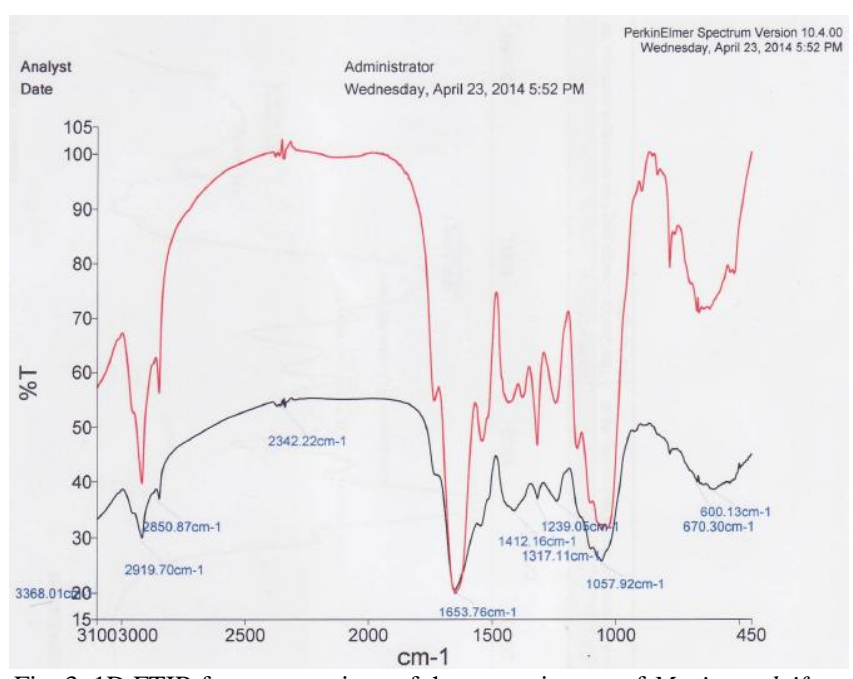

Fig. 3. 1D FTIR for a comparison of the transmittance of Moringa oleifera leaves before and after biosorption of Cd (II).

\section{CONCLUSION}

This research work has focused on using Moringa oleifera leaves as a natural (without any modification or any kind of chemical treatment), environmentally friendly biosorbent for Cd (II) removal from water. Moringa oleifera leaves can be considered as an easily, locally available, low-cost adsorbent and has a considerable high biosorption capacity. It might be considered as an alternative adsorbent for Cd (II) and other heavy metals removal in water treatment. Therefore, Moringa oleifera leaves can be considered for adsorption of $\mathrm{Cd}$ (II) from water and further studies can be carried out to improve the performance of Moringa oleifera leaves by certain process for less dosage applications.

\section{ACKNOWLEDGMENT}

The authors would like to thank Research \& Innovation Department/ Universiti Malaysia Pahang / Malaysia, for financial support to publish this paper under grant \#: RDU 140318 .

\section{REFERENCES}

[1] G. A. Drasch, "An increase of cadmium body burden for this century An investigation on human tissues," Science of the Total Environment, vol. 26, pp. 111-119, 1983.

[2] K. J. Abaliwano, A. K. Ghebremichael, and L. G. Amy, "Application of the purified Moringa oleifera coagulant for surface water treatment," Water Mill Working Paper Series, vol. 5, pp. 1-22, 2008.
[3] K. Kelly-Vargas, M. Cerro-Lopez, S. Reyna-Tellez, E. R. Bandala, and J. L. Sanchez-Salas, "Biosorption of heavy metals in polluted water, using different waste fruit cortex," Physics and Chemistry of the Earth, Parts A/B/C, vol. 37-39, pp. 26-29, 2012.

[4] M. Bilal, J. A. Shah, T. Ashfaq, S. M. H. Gardazi, A. A. Tahir, A. Pervez, H. Haroon, and Q. Mahmood, "Waste biomass adsorbents for copper removal from industrial wastewater - A review," Journal of Hazardous Materials, vol. 263, pp. 322-333, 2013.

[5] S. R. Alfarra, E. N. Ali, and M. M. Yusoff, "Removal of heavy metals by natural adsorbent: Review," International Journal of Biosciences, vol. 4, pp. 130-139, 2014.

[6] T. J. Beveridge and R. G. E. Murray, "Sites of metal deposition in the cell wall of Bacillus subtilis," Biotechnol. Appl. Biochem., vol. 141, pp. 876-887, 1980.

[7] V. K. Gupta and I. Ali, "Utilization of bagasse fly ash (a sugar industry waste) for the removal of copper and zinc from wastewater," Sep. Puri. Technol., vol. 18, pp. 131-140, 2000.

[8] X. Han, C. F. Liang, T. Q. Li, K. Wang, H. G. Huang, and X. E. Yang, "Simultaneous removal of cadmium and sulfamethoxazole from aqueous solution by rice straw biochar," J. Zhejiang Univ. Sci. B, vol. 14, pp. 640-649, 2013.

[9] J. R. Memon, S. Q. Memon, M. I. Bhanger, G. Z. Memon, A. El-Turki, and G. C. Allen, "Characterization of banana peel by scanning electron microscopy and FT-IR spectroscopy and its use for cadmium removal," Colloids Surf. B Biointerfaces, vol. 66, pp. 260-265, 2008.

[10] A. Al-Dujaili, A. Awwad, and N. Salem, "Biosorption of Cadmium (II) onto loquat leaves (Eriobotrya japonica) and their ash from aqueous solution, equilibrium, kinetics, and thermodynamic studies," International Journal of Industrial Chemistry, vol. 3, pp. 1-7, 2013.

[11] M. Verma, A. Bhandari, and R. K. Nema, "Studies on biosorption of Cadmium on Psidium guajava leave powder using statistical experimental design," Journal of Chemical and Pharmaceutical Research, vol. 2, no. 5, pp. 29-44, 2010.

[12] N. A. Babarinde, J. O. Babalola, and S. O. Sanni, "Isotherm and thermodynamic studies of the biosorption of Cd (II) from solution by maize leaf," Int. J. Phys. Sci., vol. 2, pp. 207-211, 2007.

[13] A. Mahvi, F. Gholami, and S. Nazmara, "Cadmium biosorption from wastewater by Ulmus leaves and their ash," European Journal of Scientific Research, vol. 23, pp. 197-203, 2008.

[14] N. Barka, M. Abdennouri, A. Boussaoud, and M. El-Makhfouk, "Biosorption characteristics of Cadmium (II) onto Scolymus hispanicus L. as low-cost natural biosorbent," Desalination, vol. 258, pp. 66-71, 2010.

[15] M. R. Sangi, A. Shahmoradi, J. Zolgharnein, G. H. Azimi, and M. Ghorbandoost, "Removal and recovery of heavy metals from aqueous solution using Ulmus carpinifolia and Fraxinus excelsior tree leaves," Journal of Hazardous Materials, vol. 155, pp. 513-522, 2008.

[16] H. Benaissa, "Screening of new sorbent materials for Cadmium removal from aqueous solutions," Hazard Material, vol. 132, pp. 189-195, 2006.

[17] A. Sharma and K. G. Bhattacharyya, "Azadirachta indica (Neem) leaf powder as a biosorbent for removal of Cd (II) from aqueous medium," J. Hazard. Mater, vol. 125, pp. 102-112, 2005.

[18] O. Hamdaoui, "Removal of cadmium from aqueous medium under ultrasound assistance using olive leaves as adsorbents," Chemical Engineering and Proce: Proc. Intensification, vol. 48, pp. 1157-1166, 2009.

[19] N. M. Salem, A. M. Farhan, and A. M. Awwad, "Biosorption of Cadmium (II) from Aqueous Solutions by Prunus vium Leaves," American Journal of Environmental Engineering, vol. 2, pp. 123-127, 2012.

[20] N. A. Eman, A. M. Suleyman, M. S. Hamzah, M. A. Zahangir, and M. S. Ramlan, "Production of natural coagulant from Moringa oleifera seed for application in treatment of low turbidity water," Journal of Water Resources and Protection, vol. 2, pp. 259-266, 2010.

[21] S. Kawamura, "Effectiveness of natural polyelectrolytes in water treatment," American Water Works Association, vol. 83, pp. 88-91, 1991.

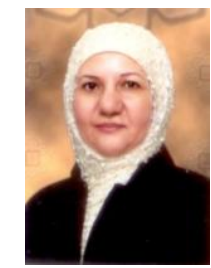

Eman N. Ali was born in Baghdad, Iraq on 29 January, 1958. She got the bachelor degree in petroleum \& mining engineering from University of Baghdad, Iraq in 1980 M.Sc. degree in chemical engineering from UKM, Malaysia in 2000, and Ph.D. degree of biotechnology engineering from IIUM, Malaysia in 2010. The major field of her study is environmental engineering (air pollution, water pollution) and Moringa oleifera 
products.

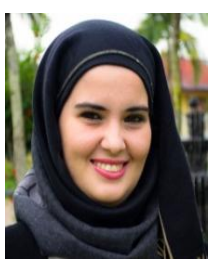

Sabreen Ramzi Alfarra was born in Abudhabi, UAE, on March 21, 1985. She got the B.Sc. degree in Applied Medical Science University of Sixth October, Egypt in 2007. She is an M.Sc. candidate at University Malaysia Pahang, Malaysia from September 2012 to present.

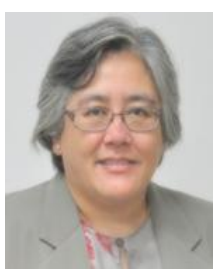

Mashitah M. Yusoff got her bachelor and $\mathrm{PhD}$ degrees from Wichita State University (USA). She is a professor of chemistry and the deputy vice chancellor on research \& innovation at Universiti Malaysia Pahang, Malaysia.
Md Lutfor Rahman was born in Bangladesh. He received the B. Sc and M. Sc degree in chemistry from University of Rajshahi. Later he obtained $\mathrm{PhD}$ degree from UPM Malaysia. Currently Dr. Lutfor Rahman is working at UMP. Dr. Lutfor Rahman has several interests including the design and synthesis of biopolymer for heavy metal extraction from industrial waste water.

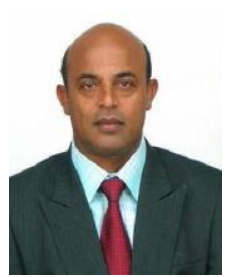

